\title{
Assessment of Particulate Air Pollution at Kalabagan and Shisumela Area Along the Mirpur Road, Dhaka
}

\author{
B. A. Begum ${ }^{a}$, M. Kamal ${ }^{\text {b }}$ A. Salam ${ }^{\text {b }}$, A. Salam ${ }^{\text {b }}$, M. A. Salam and S. K. Biswas \\ ${ }^{a}$ Chemistry Division, Atomic Energy Centre Dhaka, ${ }^{b}$ Department of Chemistry, University of Dhaka and \\ ${ }^{c}$ Clean Air \& Sustainable Environment Project, DoE
}

\begin{abstract}
Characteristics of airborne particulate matter $\left(\mathrm{PM}_{2.5}\right.$ and $\left.\mathrm{PM}_{10}\right)$ and black carbon $(\mathrm{BC})$ concentrations have been studied at Kalabagan and Shishumela sites along Mirpur corridor in Dhaka city. These sites are the major road junction of Mirpur corridor and can represent urban background. Both $\mathrm{PM}_{2.5}$ and $\mathrm{PM}_{10}$ fractions were collected simultaneously from both sites by using Air Metrics samplers. The samplings were done for 7 days from the 19-25 January and 5 days from 27- 31 January 2009 at Kalabagan and Shisumela sites respectively. It was found that the ambient $\mathrm{PM}_{2.5}$ and $\mathrm{PM}_{10}$ concentrations were much higher than the daily Bangladesh National Ambient Air Quality Standard. From reconstructed mass (RCM) method, it was found that about $90 \%$ of $\mathrm{PM}_{2.5}$ mass comes from anthropogenic sources like motor vehicles, diesel powered generator and biomass burning sources. Since the samplings were carried out during the wintertime, the long-range transport is also expected to contribute to increase the fine PM mass.
\end{abstract}

Key words: $\mathrm{PM}_{10}, \mathrm{PM}_{2.5}, \mathrm{BC}, \mathrm{RCM}$, long-range transport

\section{Introduction}

The population of Dhaka is growing very fast and becoming one of the largest cities in the world. With more than 13 million people, it is also one of the most traffic-congested city. By 2020, the population of mega city is expected to rise to 22 - 25 million. This rapid population growth together with the limited space available for new transport infrastructure will further aggravate the heavy congestion in Dhaka. Therefore, the emissions from transports, especially particulate matter (PM) have been identified as the largest contributing source that makes the Dhaka city ambient air injurious to human health (Begum et al., 2005a,Begum et al., 2004,Khaliquzzaman, 2003). Because of the reduced traffic speed, it is expected that PM concentration would be higher along the street carrying large traffic.

Previous source apportionment study, conducted for Dhaka city particulate air pollution showed fine fraction i.e., $\mathrm{PM}_{2.5}$ is dominated by vehicle emission and coarse fraction i.e., $\mathrm{PM}_{10}$ is dominated by re-suspension of road dusts. Several source apportionment studies(Begum et al., 2005a, Begum et al., 2004) of particulate matters for the Dhaka City have identified that black carbon (BC) is also one of the most important constituents of $\mathrm{PM}_{2.5}$. Combustion of fossil fuel in

\footnotetext{
* Corresponding author: E-mail: bilkisab@dhaka.net
}

transport sector has also been identified as the main source of BC in the Dhaka City. It was also found that due to longrange transport of both fine $\mathrm{PM}$ and $\mathrm{BC}($ Begum et al., 2010), the concentration of these fine PM and BC become much higher during the wintertime. Hence, the Government is trying to develop and implement appropriate strategies for managing road traffic and services in Dhaka with assistance from the World Bank. It also aimed to take assistance in the preparation of an urban transport policy and a 20-year strategic transport plan for the Dhaka Metropolitan Area (DMA).

So improvement of traffic management and road infrastructure may have direct positive impact on air quality along roadside. Thus, both the $\mathrm{PM}_{10}$ and $\mathrm{PM}_{2.5}$ size fractions are important parameters to be monitored along the roadside. The main objective of this study is to determine the existing level of particulate matter (both $\mathrm{PM}_{10}$ and $\mathrm{PM}_{2.5}$ ) and $\mathrm{BC}$ at two sites along the New Market - Mirpur traffic corridor and compare the measured levels with the Bangladesh National Ambient Air Quality Standards (BNAAQS). Efforts were also made to estimate the contribution of different sources including traffic related component to the PM fractions. 


\section{Materials and Methods}

\section{Site Selection}

The location and the positioning of the sampler were chosen carefully to achieve the purpose of this study. The first site was Kalabangan Bus Stand and Rusel Square road section, about $20 \mathrm{~m}$ North of KalaBagan over-bridge and the second site for College gate bus Stand and Shamoly road section on the Eastern side of the road about $25 \mathrm{~m}$ South of the Shishumela (Figure 1). The sites were selected near intersection so that the monitoring information could also be representative for Mirpur Road. site from 27 to 31 January 2009. The general weather condition for those days was dry and sunny. A total of 12 pairs of samples $\left(\mathrm{PM}_{10}\right.$ and $\left.\mathrm{PM}_{2.5}\right)$ were collected during the sampling periods. The description of MiniVol sampler was cited elsewhere(Begum and Biswas, 2005a). The MiniVols were programmed to sample at $5 \mathrm{lpm}$ through $\mathrm{PM}_{10}$ and $\mathrm{PM}_{2.5}$ particle size separators (impactors) and then through $2 \mathrm{~m}$ pore-size Teflon filters. The actual flow rate was $5 \mathrm{lpm}$ at ambient conditions for proper size fractionation. To ensure a constant flow of $5 \mathrm{lpm}$ through the size separator at different air temperatures and ambient pressures, the sampler flow rates were adjusted for the ambient conditions at the

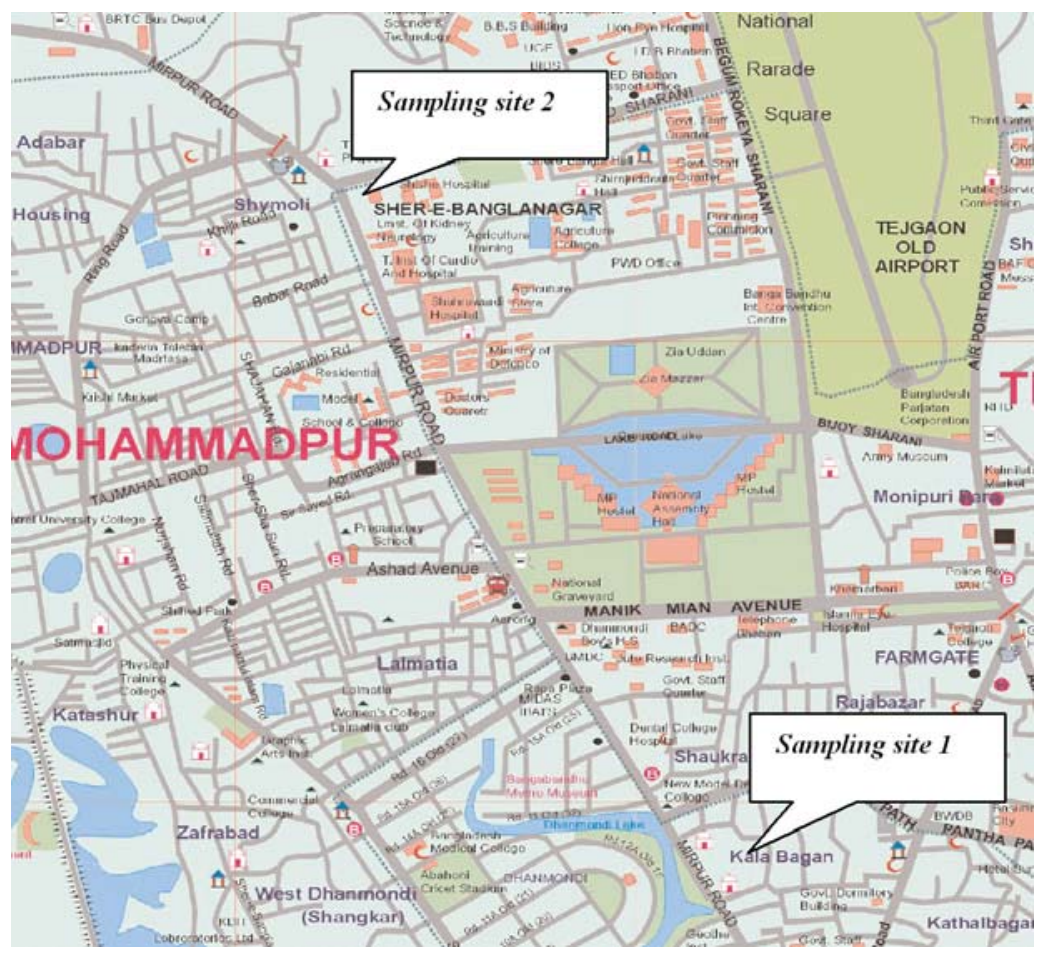

Fig. 1: Sampling location at the front of national mental institution

\section{Sampling}

Co-located PM sampling was done using two AirMetrics MiniVol samplers for collecting both $\mathrm{PM}_{10}$ and $\mathrm{PM}_{2.5}$ simultaneously. The Air Metrics MiniVol sampler (Begum and Biswas, 2005a) developed jointly by the U.S. Environmental Protection Agency (EPA) and the Lane Regional Air Pollution Authority. It was used for both $\mathrm{PM}_{10}$ and $\mathrm{PM}_{2.5}$ sampling and can be used for PM and gas sampling. Sampling campaigns were conducted for 7 days, from 19 to 25 January 2009 at Kalabagan site and 5 days at Shisumela sampling site. The samplers were placed with nozzle at the height of the breathing zone.

Both $\mathrm{PM}_{10}$ and $\mathrm{PM}_{2.5}$ samples were collected on Teflon (2.0 $\mu \mathrm{m}$ pore size) filters. The filters were conditioned at about $50 \%$ relative humidity and weighed on a microbalance prior to insertion into the filter holder. The sampling was done for $8 \mathrm{hrs}$ ( 8 am to $4 \mathrm{pm}$ ) in a day in both sites. After sampling, the filter papers were retrieved and returned to the laboratory for weighing and analysis. 
Traffic volume at the sampling site

Manual traffic volume surveys were conducted in both sites, along the Mirpur corridor during the present study. It was observed that the private car and $\mathrm{CNG}$ run auto-rickshaw are the main motorized vehicles plying along this corridor. Some buses (large and medium) are also run through the roadways. Table I summarizes the traffic volume counts survey data (from 8 am to $5 \mathrm{pm}$ ) at both sites. It has found that the number of vehicles, which run on Kalabagan road, is about $25 \%$ higher than the Shisumela road.
There is no significant buildup area around the sampling sites so that the free flowing wind can help better dispersion of pollutants that may lead to average representative concentration of pollutants.

\section{Meteorological condition}

Dhaka City has a sub-tropical climate. The wind rose plots (Fig. 2) were drawn from the BMD data starting from 2002 to 2008 and shows distinct four wind directional patterns representing four seasons in a year. During dry winterand part of the post-monsoon season, the strength of north,

Table I: Number of motor vehicles plying on road during the study at Kalabagan and Shisumela

\begin{tabular}{|c|c|c|c|c|c|c|}
\hline \multirow[t]{2}{*}{ Date } & \multicolumn{3}{|c|}{ Kalabagan } & \multicolumn{3}{|c|}{ Shisumela } \\
\hline & $\begin{array}{l}\text { Bus, } \\
\text { minibus }\end{array}$ & $\begin{array}{c}\text { Private car, } \\
\text { CNG run vehicle }\end{array}$ & $\begin{array}{l}\text { Motor } \\
\text { cycle }\end{array}$ & $\begin{array}{l}\text { Bus, } \\
\text { minibus }\end{array}$ & $\begin{array}{c}\text { Private car, } \\
\text { CNG run vehicle }\end{array}$ & $\begin{array}{l}\text { Motor } \\
\text { cycle }\end{array}$ \\
\hline $19 / 01 / 09$ & 3945 & 27840 & 2334 & & & \\
\hline $20 / 01 / 09$ & 4335 & 28884 & 2793 & & & \\
\hline 21/01/09 & 3570 & 28275 & 2805 & & & \\
\hline $22 / 01 / 09$ & 3756 & 27218 & 2741 & & & \\
\hline $23 / 01 / 09$ & 3590 & 19131 & 1696 & & & \\
\hline $24 / 01 / 09$ & 3902 & 24183 & 1984 & & & \\
\hline $25 / 01 / 09$ & 3694 & 27405 & 2727 & & & \\
\hline 27/01/09 & & & & 5289 & 28230 & 2871 \\
\hline 28/01/09 & & & & 5424 & 28155 & 3252 \\
\hline 29/01/09 & & & & 5535 & 28764 & 3435 \\
\hline $30 / 01 / 09$ & & & & 5358 & 24444 & 2106 \\
\hline $31 / 01 / 09$ & & & & 5745 & 29112 & 2628 \\
\hline
\end{tabular}

\section{Topography and road geometry at sampling site}

Topographic and geometrical characteristics of a street corridor include roads alignment, carriageway width, footpath and the surrounding buildup area that influence the dispersion of pollutants within the road. Table II summarizes the carriageway width of the sampling sites.

Table II: Carriageway width of the roadway at sampling sites

\begin{tabular}{l|c|c}
\hline \multirow{2}{*}{ Sampling site } & \multicolumn{2}{|c}{ Carriageway width } \\
\cline { 2 - 3 } & LHS & RHS \\
\hline Kalabagan & $7.8-8.3 \mathrm{~m}$ & $7.5-8.0 \mathrm{~m}$ \\
Shishumela & $8.2-8.7 \mathrm{~m}$ & $8.0-8.5 \mathrm{~m}$ \\
\hline
\end{tabular}

northwesterly wind may come from India, Nepal and Southeast China to the Bay of Bengal through Bangladesh may transport the air pollutants to the city.
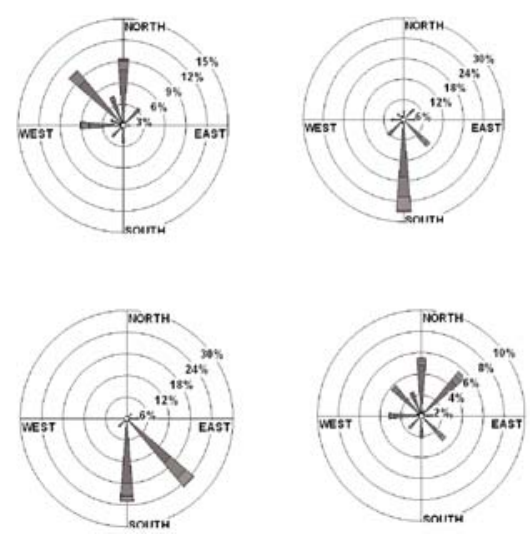

Fig. 2: Seasonal wind direction (Pre-monsoon, Monsoon, Post-monsoon and Winter respectively) at Dhaka based on wind speed data 
Moreover, during this season the wind speed is so low that the pollutants emitted from the local sources cannot travel away from the city. There are very small amounts of rainfall during winter due to north, northwesterly dry air coming over the land surface and the whole meteorological situation acts in favor to the severe air pollution episode over the city in combination with local and transboundary pollution effect.

\section{PM mass and black carbon measurement}

PM mass was measured in the Chemistry Lab of the Atomic Energy Centre, Dhaka (AECD). The $\mathrm{PM}_{10}$ and $\mathrm{PM}_{2.5}$ samples were determined by weighing the filters before and after exposure using a microbalance. The filters were equilibrated for $24 \mathrm{~h}$ at constant humidity of $50 \%$ and temperature $\left(22^{\circ} \mathrm{C}\right)$ in the balance room before every weighing. A Po-210 (alpha emitter) electrostatic charge eliminator was used to eliminate the static charge accumulated on the filters before each weighing. The difference in weights for each filter was calculated and the mass concentrations for each $\mathrm{PM}_{10}$ or $\mathrm{PM}_{2.5}$ samples were determined.

The concentration of $\mathrm{BC}$ in both $\mathrm{PM}_{10}$ and $\mathrm{PM}_{2.5}$ samples were determined by reflectance measurement in AECD laboratory using an Evans Electroselenium Limited (EEL) type Smoke Stain Reflectometer (Biswas et al., 2003). Secondary standards of known black carbon concentrations were used to calibrate the reflectometer. The concentrations are defined based on the amount of reflected light that is absorbed by the filter sample and an assumed mass absorption coefficient. It is related to the concentration of light absorbing carbon through standards of carbon with known areal density. Iron (Fe) has a moderate light absorption coefficient and can have some limited influence on the $\mathrm{BC}$ value measured by reflectance. The uncertainty associated with the $\mathrm{BC}$ measurement is rather high (4-9\%), and therefore, the influence of variation in $\mathrm{Fe}$ concentration on $\mathrm{BC}$ measurement has been neglected.

\section{Elemental Analysis}

The samples were analyzed by X-ray Fluorescence method and the method of analysis were described elsewhere (Begum and Biswas, 2005b). A radioisotope-induced energy dispersive X-ray fluorescence (EDXRF) (Bernasconi et al., 2000, Molnar et al., 2005) Spectrometer was used to analyze the elemental composition of all of the filter samples.

\section{Reconstructed mass (RCM)}

The analysis of PM samples provided opportunities of detecting sufficient number of elements and then it is easy to develop fingerprints of a variety of particle sources(Begum et al., 2006b). It is useful to combine some of these elements and estimate the concentrations of compounds likely to represent most of the measured element such as estimating the amount of ammonium sulfate from the measured sulfur concentration. It is also possible to derive other combinations of pure elements that represent signatures for interesting aerosol components. These elements are called pseudo-elements such as "soil". Thus these composite variables and pseudo-elements help to have a better understanding of possible sources and their contributions to the average ambient aerosol (Malm et al., 1994).

\section{Smoke}

Fine potassium is an accepted indicator for smoke from biomass burning/brick kiln. Most biomass fuels are characterized by high-alkali contents (Jenkins et al., 1998) leading to high concentrations of fine aerosols in the flue gases (Jimenez and Ballester, 2004). In order to obtains a reliable smoke indicator from the fine potassium, it is necessary to subtract the fine potassium associated with soil component from total K (Weast, 1977). Hence, smoke is obtained by using the following equation,

Smoke $=($ Ktot $-0.6 * F e)$

\section{Soil}

Windblown soil is composed mainly of the oxides of $\mathrm{Mg}, \mathrm{Al}$, $\mathrm{Si}, \mathrm{Ca}, \mathrm{Ti}$ and Fe with other many trace elements (Weast, 1977). The average composition of sandstone and sedimentary rocks and the summation of the 5 major oxides of $\mathrm{Al}, \mathrm{Si}$, $\mathrm{Ca}$, Ti and $\mathrm{Fe}$ account for more than $85 \%$ of the total composition. So the equation for soil is

Soil $=2.20 * \mathrm{Al}+2.49 * \mathrm{Si}+1.63 * \mathrm{Ca}+1.94 * \mathrm{Ti}+2.42 * \mathrm{Fe}$

This equation assumes that the two common oxides of iron $\mathrm{Fe}_{2} \mathrm{O}_{3}$ and $\mathrm{FeO}$ occur in equal proportions. The factor of 2.42 for iron also includes the estimate for $\mathrm{K}_{2} \mathrm{O}$ in soil through the $(\mathrm{K} / \mathrm{Fe})=0.6$ ratio for sedimentary soils. The sum of all of the composite variables is expected to provide a reasonable estimation of $\mathrm{PM}_{10}$ and $\mathrm{PM}_{2.5}$ mass for comparison with the measured gravimetric mass collected on the filters. 
The definition of the reconstructed mass (RCM) is,

$\mathrm{RCM}=\left(\mathrm{NH}_{4}\right)_{2} \mathrm{SO}_{4}+\mathrm{Salt}+\mathrm{Soil}+$ Smoke $+\mathrm{Zn}+\mathrm{Cu}+\mathrm{BC}+\mathrm{OC}$

Where $\left(\mathrm{NH}_{4}\right)_{2} \mathrm{SO}_{4}$, and Salt are the terms for sulphate and sea salt. Because of the analytical limitations, these terms have been omitted for lack of the data needed to estimate their concentrations.

\section{Results and Discussion}

\section{PM and BC Concentrations}

Al together twelve $\mathrm{PM}_{10}$ and $\mathrm{PM}_{2.5}$ samples were collected and analyzed for gravimetric mass, black carbon and elemental concentrations during the study. Table III shows the daily $\mathrm{PM}_{10}, \mathrm{PM}_{2.5}, \mathrm{BC}, \mathrm{BC} / \mathrm{PM}_{2.5}$, and $\mathrm{PM}_{2.5} / \mathrm{PM}_{10}$, mass ratios during the sampling periods. The data indicate that more than 64\% (at Kalabagan) and 47\% (at Shisumela, Syyamoli) of the $\mathrm{PM}_{10}$ mass respectively were fine particles with aerodynamic diameter less than $2.5 \mu \mathrm{m}$ in majority of the days, which were mainly from anthropogenic origin. It may be due to the influence of traffic-induced dust from abrasion and resuspension, which was dominated by exhaust pipe emissions and also other anthropogenic activities like waste burning and wind blown dust from the playground. It was found that about 27\% (at Kalabagan) and 47\% (at Shisumela, Syyamoli) of $\mathrm{PM}_{2.5}$ was $\mathrm{BC}$ mass. Transport related emissions are major source of $\mathrm{BC}$, and while longrange transportation from fossil fuel related sources and biomass burning could be other substantial sources of BC(Viidanoja et al., 2002). Shisumela site predominated by commercial activities than Kalabagan area, hence BC could also emit from the diesel-powered generators used during power cuts. $\mathrm{BC}$ has a higher contribution during the dry season. Black carbon (BC) is a tracer of primary anthropogenic emissions and its variability reflects changes in source strengths, long-range transport and atmospheric mixing characteristics.

\section{Comparison with Semi-residential site}

The average $\mathrm{PM}_{10}, \mathrm{PM}_{2.5}$ and $\mathrm{BC}$ concentrations are compared with those concentrations measured in a separate study during the sampling period at a semi-residential area at Dhaka and is given in Table IV. In general, both PM and BC concentrations in the study area are significantly higher than the corresponding concentrations at semi-residential area.

It was also observed that the ratio of $\mathrm{PM}_{2.5} / \mathrm{PM}_{10}$ in study areas are about 1.36 and 0.96 times higher than the ratio of $\mathrm{PM}_{2.5} / \mathrm{PM}_{10}$ at semi residential area (Table IV). This higher ratio indicates that relative $\mathrm{PM}_{2.5}$ fraction i.e., anthropogenic component of PM is higher at the study area. The main reason of higher $\mathrm{PM}_{2.5}$ fraction expected to be the influence of playground and open burning sources surrounding the sampling sites. Moreover, traffic related emission from the busy road with higher traffic density along the northern side of the sampling site which links the western and eastern part of Dhaka city might have additional influence on the observed higher $\mathrm{PM}_{2.5}$ concentration. The semi-residential site is located within the Atomic Energy Centre, Dhaka University Campus with relatively less traffic. The $\mathrm{BC} / \mathrm{PM}_{2.5}$ ratios are 3.62 and 6.40 times higher with respect to semi-residential in Kalabagan and Shisumela sites. This indicates that anthropogenic activities (diesel powered generator for power supply) in Shisumela are much higher than Kalabagan site because Shisumela is a commercial area. BC also may emit

Table III: The average value of $\mathrm{PM}_{10}, \mathrm{PM}_{2.5}$ and ratios of $\mathrm{BC} / \mathrm{PM}_{2.5}$, and $\mathrm{PM}_{2.5} / \mathrm{PM}_{10}$ during the sampling period at Kalabagan and Shisumela

\begin{tabular}{l|c|c|c|c|c|c|c|c|c}
\hline \multirow{2}{*}{ Date } & \multicolumn{4}{|c|}{ Kalabagan } & & \multicolumn{4}{|c}{ Shisumela } \\
\cline { 2 - 4 } \cline { 7 - 9 } & $\mathrm{PM}_{10}$ & $\mathrm{PM}_{2.5}$ & $\mathrm{BC}_{\mathrm{PM}} \mathrm{PM}_{2.5}$ & $\mathrm{PM}_{2.5} / \mathrm{PM}_{10}$ & Date & $\mathrm{PM}_{10}$ & $\mathrm{PM}_{2.5}$ & $\mathrm{BC} / \mathrm{PM}_{2.5}$ & $\mathrm{PM}_{2.5} / \mathrm{PM}_{10}$ \\
\hline $01 / 19 / 09$ & 372 & 231 & 0.27 & 0.62 & $01 / 27 / 09$ & 295 & 126 & 0.51 & 0.43 \\
$01 / 20 / 09$ & 348 & 195 & 0.27 & 0.56 & $01 / 28 / 09$ & 357 & 170 & 0.44 & 0.47 \\
$01 / 21 / 09$ & 260 & 146 & 0.32 & 0.56 & $01 / 29 / 09$ & 321 & 120 & 0.50 & 0.37 \\
$01 / 22 / 09$ & 305 & 200 & 0.30 & 0.66 & $01 / 30 / 09$ & 310 & 154 & 0.45 & 0.50 \\
$01 / 23 / 09$ & 359 & 233 & 0.30 & 0.65 & $01 / 31 / 09$ & 319 & 159 & 0.44 & 0.50 \\
$01 / 24 / 09$ & 369 & 262 & 0.27 & 0.71 & & & & & \\
$01 / 25 / 09$ & 545 & 385 & 0.19 & 0.71 & & & & & \\
\hline
\end{tabular}


Table IV: Comparison of $\mathrm{PM}_{10}, \mathrm{PM}_{2.5}$ and $\mathrm{BC}$ concentrations $\left(\mu \mathrm{gg} / \mathrm{m}^{3}\right)$ at semi-residential area and $\mathrm{Kalabagan}$ site

\begin{tabular}{|c|c|c|c|c|c|c|}
\hline \multirow[t]{2}{*}{ Parameter } & \multicolumn{2}{|c|}{$\begin{array}{l}\text { Semi-residential area } \\
\text { (24-hours average) }\end{array}$} & \multicolumn{2}{|c|}{$\begin{array}{c}\text { Kalabagan site (8-hours } \\
\text { average) }\end{array}$} & \multicolumn{2}{|c|}{$\begin{array}{c}\text { Shisumela site (8-hours } \\
\text { average) }\end{array}$} \\
\hline & Average & SD & Average & SD & Average & SD \\
\hline $\mathrm{PM}_{10}$ & 227 & 32.6 & 366 & 88.9 & 320 & 22.9 \\
\hline $\mathrm{PM}_{2.5}$ & 108 & 30.1 & 236 & 75.4 & 146 & 21.6 \\
\hline $\mathrm{BC}$ & 7.80 & 1.82 & 61.7 & 10.0 & 67.5 & 5.54 \\
\hline $\mathrm{OC}$ & & & 142 & 22.9 & 40.5 & 3.30 \\
\hline
\end{tabular}

from the brick kilns located around Dhaka city. It is to be noted that cluster of brickfields that are situated in the western part of Dhaka city are closer to Shisumela site than Kalabagan location.

The 8-h average values for both $\mathrm{PM}_{10}$ and $\mathrm{PM}_{2.5}$ masses are much higher than the Bangladesh national air quality standard (24h average), which are set at $165 \mu \mathrm{g} / \mathrm{m}^{3}$ and 65 $\mu \mathrm{g} / \mathrm{m}^{3}$, respectively. The major source of $\mathrm{PM}_{2.5}$ comes from anthropogenic activities(Begum et al., 2004).

Time series of $\mathrm{PM}$ concentration and dependence on meteorology

The time series of the average 8-h $\mathrm{PM}_{2.5}$ and $\mathrm{PM}_{10}$ mass concentrations were analyzed throughout the sampling period. The reasons for the higher PM concentration during the winter are not only seasonal fluctuations of the emissions from local sources, but also meteorological effects. According to the meteorological conditions (Figure 2), it was established that during the wintertime wind mainly comes from the north and northwest directions(Begum et al., 2006a).

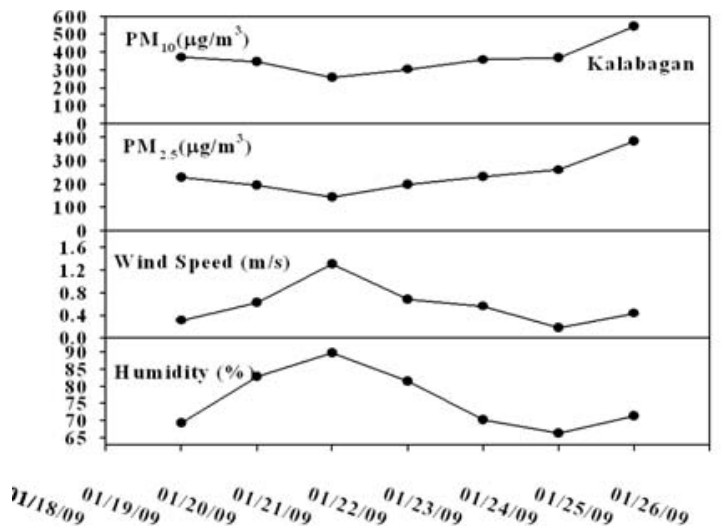

Figure 3 shows the relative plotting of $\mathrm{PM}_{2.5}$ mass concentration, humidity and wind speed to observe the dependence of $\mathrm{PM}_{2.5}$ concentration on those meteorological parameters during the sampling periods. It was found that with the increase of wind speed during these dry season, the $\mathrm{PM}_{2.5}$ mass decreased (Figure 3) and when the relative humidity becomes maximum the fine PM concentration also becomes lower as the PM mass coagulates with the water droplet. But with the decrease of humidity and lower wind speed, the fine PM concentrations also tend to increase.

\section{Source apportionment from Reconstructed Mass (RCM)}

All the collected samples (both $\mathrm{PM}_{2.5}$ and $\mathrm{PM}_{10}$ ) were analyzed by XRF method and $\mathrm{BC}$ concentrations were measured by reflectance measurements. The $\mathrm{OC}$ contents were estimated from suitable EC (BC)/TC ratios obtained from literature. Emissions from diesel engines as well as from oil- and coal-fired stationary sources exhibit $\mathrm{EC}(\mathrm{BC}) / \mathrm{TC}$ ratios in the range of 0.6-0.7(Cass et al., 1982,Rau, 1989). In contrast, for emissions from biomass combustion, $\mathrm{EC}(\mathrm{BC}) / \mathrm{TC}$ ratios are around 0.3 that have been reported in prior studies (Cachier

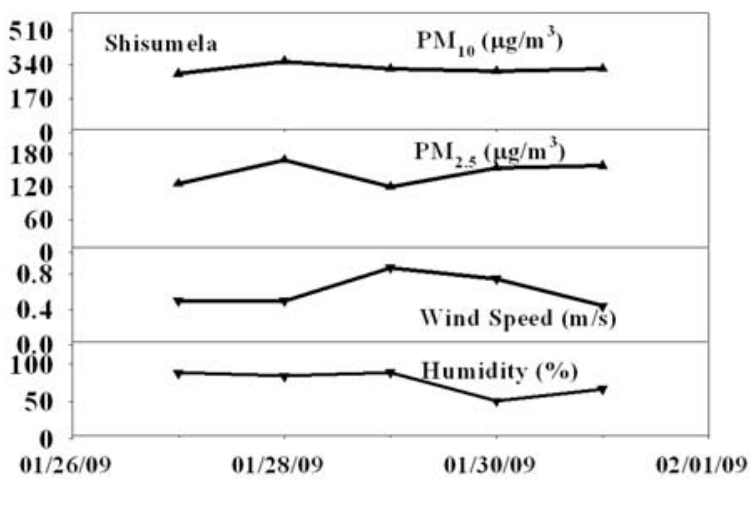

Fig. 3: Variation of $\mathrm{PM}_{10}$ and $\mathrm{PM}_{2.5}$ mass with the change of meteorological parameters during the sampling time at Kalabagan and Shisumela respectively 
et al., 1991,Cachier et al., 1995). In the present study $\mathrm{EC}(\mathrm{BC}) / \mathrm{TC}$ ratio of 0.3 was used to estimate OC contents in the samples as it was reported earlier that PM in Dhaka is enriched with emissions from biomass burning and $\mathrm{OC}$ emissions from CNG burning expected to be low.

The elemental compositions along with $\mathrm{BC}$ and $\mathrm{OC}$ concentrations of both the fractions are presented in Table $\mathrm{V}$ and Table VI for Kalabagan and Shisumela sites respectively. These elemental composition data including $\mathrm{BC}$ and $\mathrm{OC}$ were further used for source identifications using RCM method.

The available elemental, $\mathrm{OC}$ and $\mathrm{BC}$ concentration data were used to estimate the possible sources and their contributions to the average ambient PM pollutants. The sum of all the composite variables discussed in the previous section would provide a reasonable estimate of the total $\mathrm{PM}_{10}$ and $\mathrm{PM}_{2.5}$ mass for comparison with the measured gravimetric mass of both $\mathrm{PM}_{10}$ and $\mathrm{PM}_{2.5}$ on the Teflon filters. So, the

Table V: The elemental concentrations of $\mathrm{PM}_{2.5}$ mass Concentration $\left(\mu \mathrm{g} / \mathrm{m}^{3}\right)$ collected during the sampling periods at Kalabagan and Shishumela

\begin{tabular}{|c|c|c|c|c|c|c|c|c|c|c|}
\hline \multirow[t]{2}{*}{ Date } & \multicolumn{10}{|c|}{ Kalabagan } \\
\hline & $\mathrm{Al}$ & $\mathrm{Si}$ & $\mathrm{K}$ & $\mathrm{Ca}$ & $\mathrm{Ti}$ & $\mathrm{Fe}$ & $\mathrm{Cu}$ & $\mathrm{Zn}$ & $\mathrm{BC}$ & $\mathrm{OC}$ \\
\hline 19/01/09 & 0.24 & 0.82 & 3.80 & 3.55 & 1.91 & 4.12 & 1.23 & 0.78 & 61.5 & 142 \\
\hline 20/01/09 & 0.00 & 0.01 & 3.96 & 2.41 & 1.75 & 0.06 & 0.06 & 0.18 & 52.1 & 120 \\
\hline 21/01/09 & 0.21 & 0.72 & 1.49 & 2.94 & 1.94 & 3.62 & 0.14 & 1.29 & 46.1 & 106 \\
\hline $22 / 01 / 09$ & 0.16 & 0.55 & 0.80 & 3.10 & 1.95 & 2.77 & 1.05 & 1.16 & 59.5 & 137 \\
\hline 23/01/09 & 0.28 & 0.96 & 2.36 & 3.74 & 2.19 & 4.80 & 0.20 & 1.87 & 69.0 & 159 \\
\hline 24/01/09 & 0.26 & 0.88 & 6.86 & 3.87 & 1.69 & 4.40 & 0.85 & 1.27 & 70.8 & 163 \\
\hline \multirow[t]{2}{*}{$25 / 01 / 09$} & 0.37 & 1.26 & 1.91 & 2.32 & 9.20 & 6.31 & 0.26 & 24.7 & 72.7 & 167 \\
\hline & \multicolumn{10}{|c|}{ Shishumela } \\
\hline $27 / 01 / 09$ & 0.26 & 0.89 & 6.86 & 2.78 & 1.75 & 4.48 & 0.04 & 0.09 & 64.3 & 38.6 \\
\hline 28/01/09 & 0.23 & 0.78 & 2.38 & 0.08 & 2.08 & 3.91 & 1.41 & 0.54 & 74.0 & 44.4 \\
\hline 29/01/09 & 0.23 & 0.80 & 2.54 & 5.66 & 0.77 & 4.02 & 0.86 & 0.08 & 59.8 & 35.9 \\
\hline $30 / 01 / 09$ & 0.44 & 1.50 & 2.26 & 3.24 & 23.4 & 7.54 & 1.14 & 6.87 & 70.0 & 42.0 \\
\hline $31 / 01 / 09$ & 0.32 & 1.09 & 1.65 & 0.67 & 5.44 & 5.46 & 0.20 & 2.17 & 69.4 & 41.7 \\
\hline
\end{tabular}

Table VI: The elemental concentrations of $\mathbf{P M}_{10}$ mass collected during the sampling periods at Kalabagan and Shishumela

\begin{tabular}{|c|c|c|c|c|c|c|c|c|c|c|}
\hline \multirow[t]{2}{*}{ Date } & \multicolumn{10}{|c|}{ Kalabagan } \\
\hline & $\mathrm{Al}$ & $\mathrm{Si}$ & $\mathrm{K}$ & $\mathrm{Ca}$ & $\mathrm{Ti}$ & $\mathrm{Fe}$ & $\mathrm{Cu}$ & $\mathrm{Zn}$ & $\mathrm{BC}$ & $\mathrm{OC}$ \\
\hline $19 / 01 / 09$ & 0.75 & 2.57 & 10.2 & 6.63 & 15.9 & 12.9 & 1.00 & 8.30 & 66.0 & 152 \\
\hline 20/01/09 & 0.63 & 2.17 & 6.65 & 7.53 & 5.44 & 10.9 & 0.03 & 0.14 & 62.4 & 144 \\
\hline 21/01/09 & 0.01 & 0.03 & 1.79 & 0.75 & 1.32 & 0.17 & 0.08 & 0.28 & 57.4 & 132 \\
\hline 22/01/09 & 0.48 & 1.64 & 0.46 & 6.80 & 2.88 & 8.21 & 0.27 & 0.39 & 67.7 & 156 \\
\hline 23/01/09 & 0.02 & 0.07 & 0.17 & 1.92 & 0.76 & 0.34 & 0.01 & 0.13 & 69.2 & 159 \\
\hline $24 / 01 / 09$ & 0.43 & 1.46 & 4.55 & 0.32 & 0.67 & 7.31 & 0.28 & 0.18 & 73.5 & 169 \\
\hline \multirow[t]{2}{*}{$25 / 01 / 09$} & 0.94 & 3.23 & 0.32 & 6.10 & 24.9 & 16.2 & 0.21 & 34.7 & 87.4 & 201 \\
\hline & \multicolumn{10}{|c|}{ Shishumela } \\
\hline $27 / 01 / 09$ & 1.13 & 3.86 & 2.39 & 0.21 & 32.5 & 19.3 & 1.00 & 10.6 & 67.2 & 155 \\
\hline 28/01/09 & 0.83 & 2.85 & 1.31 & 6.52 & 31.0 & 14.3 & 0.94 & 8.29 & 80.7 & 186 \\
\hline 29/01/09 & 0.81 & 2.78 & 0.88 & 9.88 & 1.48 & 13.9 & 0.89 & 0.52 & 65.0 & 149 \\
\hline $30 / 01 / 09$ & 0.74 & 2.55 & 9.31 & 1.62 & 4.09 & 12.8 & 0.94 & 1.15 & 84.6 & 195 \\
\hline $31 / 01 / 09$ & 0.77 & 2.65 & 9.9 & 8.31 & 4.36 & 13.3 & 1.09 & 1.42 & 76.0 & 175 \\
\hline
\end{tabular}


definition of the reconstructed mass (RCM) would be,

$\mathrm{RCM}=\left(\mathrm{NH}_{4}\right)_{2} \mathrm{SO}_{4}+\mathrm{Salt}+\mathrm{Soil}+\mathrm{Smoke}+\mathrm{Zn}+\mathrm{Cu}+\mathrm{BC}+\mathrm{OC}$

The accuracy of this equation was tested (Begum et al., 2006b) by comparing RCM with the gravimetric weight of the PM. The average RCM accounted for about $65-87 \%$ and $79-119 \%$ of the measured mass for $\mathrm{PM}_{10}$ and $\mathrm{PM}_{2.5}$ respectively in this study. OC has been calculated theoretically considering $\mathrm{OC}$ emission only from biomass burning, which in some cases gives RCM over $100 \%$. The samples were collected at road canyons so, it is expected that part of OC would be emissions from gasoline/CNG burning in vehicles, thus the ratio will be to some extent higher and the estimated OC concentrations will be lower giving better mass closer. Table VII gives the percentage of source contributions to $\mathrm{PM}$ from RCM calculation for $\mathrm{PM}_{2.5}$ and $\mathrm{PM}_{10}$ particulate matter collected at both sites in Dhaka for the study period.

Table VII: Percentage of source contributions to PM from RCM calculation

\begin{tabular}{l|c|c|c|c}
\hline \multirow{2}{*}{ Parameter } & \multicolumn{2}{|c|}{ Kalabagan } & \multicolumn{2}{c}{ Shisumela } \\
\cline { 2 - 5 } & $\mathrm{PM}_{2.5}$ & $\mathrm{PM}_{10}$ & $\mathrm{PM}_{2.5}$ & $\mathrm{PM}_{10}$ \\
\hline Soil dust & 8.68 & 13.8 & 22.6 & 24.5 \\
Smoke & 0.72 & 0.29 & 0.60 & 0.54 \\
Tire ware & 0.27 & 0.11 & 0.51 & 0.29 \\
Zn & 0.50 & 0.61 & 1.36 & 1.32 \\
Black carbon (BC) & 27.2 & 25.8 & 46.9 & 22.3 \\
Organic carbon (OC) & 62.6 & 59.3 & 28.1 & 51.4 \\
\hline
\end{tabular}

It is observed that in both places, maximum pollution contribution comes from biomass burning and motor vehicles in $\mathrm{PM}_{2.5}$ mass and estimated contributions are over $89.8 \%$ in Kalabagan and $75 \%$ in Shisumela. In case of $\mathrm{PM}_{10}$ mass, the highest contributors are the $\mathrm{BC}$ and $\mathrm{OC}$, which accounts for about $85 \%$ (Kalabagan) and $74 \%$ (Shisumela) of the total mass. Although maximum fraction of the $\mathrm{BC}$ and $\mathrm{OC}$ expected to be from vehicular emission but $\mathrm{BC} / \mathrm{OC}$ may also originate from the unburned fuel or from the biomass burning/brick kiln (Begum et al., 2005b). About 8.68\% (Kalabagan) and 22.6\% (Shisumela) of the $\mathrm{PM}_{2.5}$ masses are soil dust source and $0.72 \%$ (Kalabagan) and $0.60 \%$ (Shisumela) of $\mathrm{PM}_{2.5}$ masses are smoke. During the sampling periods, waste materials were burned near the sampling sites, which is the signature of smoke.

\section{Long Range Transport}

Since $\mathrm{PM}_{2.5}$ fractions have relatively high residence time, and this fraction could have regional contribution apart from local sources. It was observed from the wind direction pattern that during the wintertime, the wind comes mainly from north and northwest directions(Begum et al., 2006a). There are some sources locations in these areas like Afganistan, Bay of Bengal, Arabian Sea, Oman and potentially can contribute to local PM (especially fine PM) levels through longrange transport, because of its relatively longer suspension time. Such possibility was explored by using back trajectory models(Begum et al., 2010). The Hybrid Single Particle Lagrangian Integrated Trajectory (HYSPLIT 4) model (Draxler and Rolph, 2003) was used to calculated the air mass backward trajectories for days with high impacts of

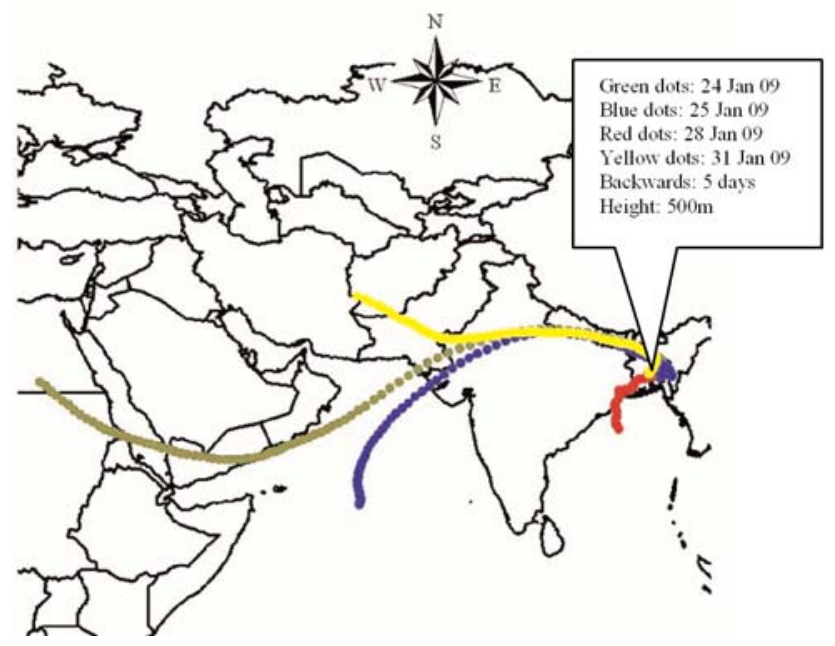

Fig. 4: Backward trajectories arriving Dhaka on 24, 25, 28, 31 January 2009 computed at the NOAA Air Resources Laboratory HYSPLIT site

fine particles. Backward trajectories starting at height of 500 $\mathrm{m}$ above the ground level were computed using the vertical mixing model. A starting height of $500 \mathrm{~m}$ has been used elsewhere (Cheng et al., 1993). This height is approximately the height of the mixing layer and has generally found as useful height for such analyses (Zeng and Hopke, 1989). This height was chosen to diminish the effects of surface friction and to represent winds in the lower boundary layer. The fine PM has ability to travel long distance(Begum et al., 2010), therefore the days which have high fine PM concentrations were selected to calculate the backwards trajectories using 
HYSPLIT 4. Archived REANALYSIS meteorological data were used as input. The latitude/longitude of Dhaka was used and trajectories were computed backward in time up to 120 hours (5 days). Tick marks on the trajectory plots indicate 6-hour movement locations. Figure 4 shows the PM levels on 24, 25, 28, 31 January 2009 could be influenced by the contributions from northwesterly and southerly. The results indicate that $\mathrm{PM}$ concentrations in winter may also be influenced by transboundary air pollution.

\section{Acknowledgement}

The work is financially supported partly by the International Atomic Energy Agency (IAEA) under the Regional Cooperative Agreement (RCA) project RAS/7/015 and the Ministry of Science and Technology, Government of the People's Republic of Bangladesh under the special grant. Without the support of Atomic Energy Centre, Dhaka, the work could not be undertaken. The authors thankfully acknowledge those assistances and support.

\section{References}

Begum B. A. and Biswas S. K. (2005a). Comparison of PM collection efficiency of Gent and Airmatrics MiniVol Portable Air Sampler. Nuclear Science and Application I14: 79-83.

Begum B. A. and Biswas S. K. (2005b). Quality assurance test for trace element analysis in Marine Sediment using radioisotope induced XRF. Nuclear Science and Applications 14: 57-62.

Begum B. A., Biswas S. K. and Hopke P. K. (2006a). Temporal variations and spatial distribution of ambient PM2.2 and PM10 concentrations in Dhaka, Bangladesh. The Science of the Total Environment 358: $36-45$.

Begum B. A., Biswas S. K., Hopke P. K. and Cohen D. D. (2006b). Multi-element analysis and characterization of atmospheric particulate pollution in Dhaka. Aerosol and Air Quality Research 6: 334-359.

Begum B. A., Biswas S. K., Kim E., Hopke P. K. and Khaliquzzaman M. (2005a). Investigation of sources of atmospheric aerosol at a hot spot area in Dhaka, Bangladesh. J. Air and Waste Management Association 55: 227-240.
Begum B. A., Biswas S. K., Markwics A. and Hopke P. K. (2010). Identification of sources of fine and coarse particulate matter in Dhaka, Bangladesh. Aerosol and Air Quality Research 10: 345-353.

Begum B. A., Hopke P. K. and Zhao W. (2005b). Source identification of fine particles in Washington, DC, by expanded factor analysis modeling. Environmental Science and Technology 39: 1129-1137.

Begum B. A., Kim E., Biswas S. K. and Hopke P. K. (2004). Investigation of sources of atmospheric aerosol at urban and semi-urban areas in Bangladesh. Atmos. Environ. 38: 3025-3038.

Bernasconi G., Tajani A. and Kregsamer P. (2000). Mannual for QXAS/AXIL. Version 3.5, IAEA, Vienna.

Biswas S. K., Tarafdar S. A., Islam A., Khaliquzzaman M. , Tervahattu H. and Kupiainen K. (2003). Impact of unleaded gasoline introduction on the concentration of lead in the air of Dhaka, Bangladesh. J. Air and Waste Management Association 53: 1355-1362.

Cachier H., Ducret J., Bremond M. P., Youbue V., Lacaux J. P. , Gaudichet A. and Baudet J. (1991). Biomass burning aerosols in a savanna region of the Ivory Coast in Global Biomass Burning, ed. J. S. Levine, MIT press, Cambridge, MA. 174-180.

Cachier H., Liousse C., Buat-Menard P. and Gaudichet A. (1995). Particulate content of Savanna fire emissions. J. Atmospheric Chemistry 22: 123-148.

Cass G. R., Boone P. M. and Macias E. S. (1982). Emission and air quality relationships for atmospheric carbon particles in Loss Angeles, Particulate carbon: Atmospheric Life Cycle, ed. G.T.Wolff and R.L. KlimischPlenum Press, New York.

Cheng M.-D., Hopke P. K., Barrie L., Rippe A., Olson M. and Landsberger S. (1993). Qualitative determination of source regions of aerosol in Canadian high Arctic. Environmental Science and Technology 27:2063-2071.

Draxler R. R. and Rolph. G. D. (2003). HYSPLIT 4(Hybrid Single-Particle Lagrangian Integrated Trajectory) Model access via NOAA ARL READY Website (http://www.arl.noaa.gov/ready/hysplit4.html). NOAA Air Resources Laboratory, Silver Spring, MD.. 
Jenkins B. M., Baxter L. L., Miles T. R. J. and Miles T. R. (1998). Combustion properties of biomass. Fuel proc. technology 54: 17-46.

Jimenez S. and Ballester J. (2004). Formation and emission of submicron particles in pulverzed olive residue combustion. Aerosol Science and Technology 38: 707-723.

Khaliquzzaman M. (2003). An Assessment of the Impact of Removal of Baby Taxis on Air Quality in Dhaka, Personal Communication, Consultant, World Bank, Dhaka Office.

Malm W. C., Sisler J. F., Huffman D., Eldred R. A. and Cahill T. A. (1994). Spatial and seasonal trends in particle concentration and optical extinction in the United States. J. Geophysical Research 99: 1347-1370.

Molnar P., Gustafson P., Johannesson S., Boman J., Barregard L. and Sallsten G. (2005). Domestic wood burning and $\mathrm{PM}_{2.5}$ trace elements: Personal exposure, indoor and outdoor levels. Atmos. Environ. 39: 26432653.
Rau J. A. (1989). Aerosol Science and Technology 10: 181192.

Viidanoja J., Sillanpaa M., Laakia J., Kerminen V. M., Hillamo R., Aarnio P. and Koskentalo T. (2002). Organic and black carbon in $\mathrm{PM}_{2.5}$ and $\mathrm{PM}_{10}: 1$ year of data from an urban site.

Weast R. C. (1977). CRC Handbook of Chemistry and Physics, 57th edn (Ohio,USA, CRC press Inc.).

Zeng Y. and Hopke P. K. (1989). A study on the sources of acid precipitation in Ontario, Canada. Atmos. Environ. 23: 1499-1509.

Received: August 29, 2010;

Accepted : December 27, 2010 